\title{
Outbreak of chicken flu rattles Hong Kong
}

\section{David Cyranoski, Hong Kong}

Despite a huge poultry cull, Hong Kong is struggling against an outbreak of a potentially deadly chicken flu virus.

The virus, H5, normally lives in the intestines of aquatic birds. Although it cannot infect mammalian intestines, it can attack the respiratory tract, causing flu-like symptoms and, in extreme cases, pneumonia. In 1997, the H5N1 strain killed six people in Hong Kong.

Although the H5 strains found in Hong Kong this year are not thought to be transmissible to humans, the authorities acted swiftly to contain the outbreak. In May, around 1.3 million fowl were killed, including almost the entire stock of chickens, and imports were banned.

But on 5 July, only three weeks after the ban was lifted, traces of a related virus were found in fecal samples from a chicken imported from China. Researchers are now sequencing the genome of the virus, in an effort to determine its identity and its disease-causing potential in both chickens and humans.

The May slaughter, which cost the Hong Kong government HK\$245 million (US\$32 million) in compensation, is seen as overkill by some researchers. "The reaction to the virus was completely overdone," says a food hygienist at one Hong Kong university, who did not want to be identified.

But Nikolaus Sucher, a molecular biologist at Hong Kong University of Science and Technology, believes the decisive action may have prevented a serious international epidemic.

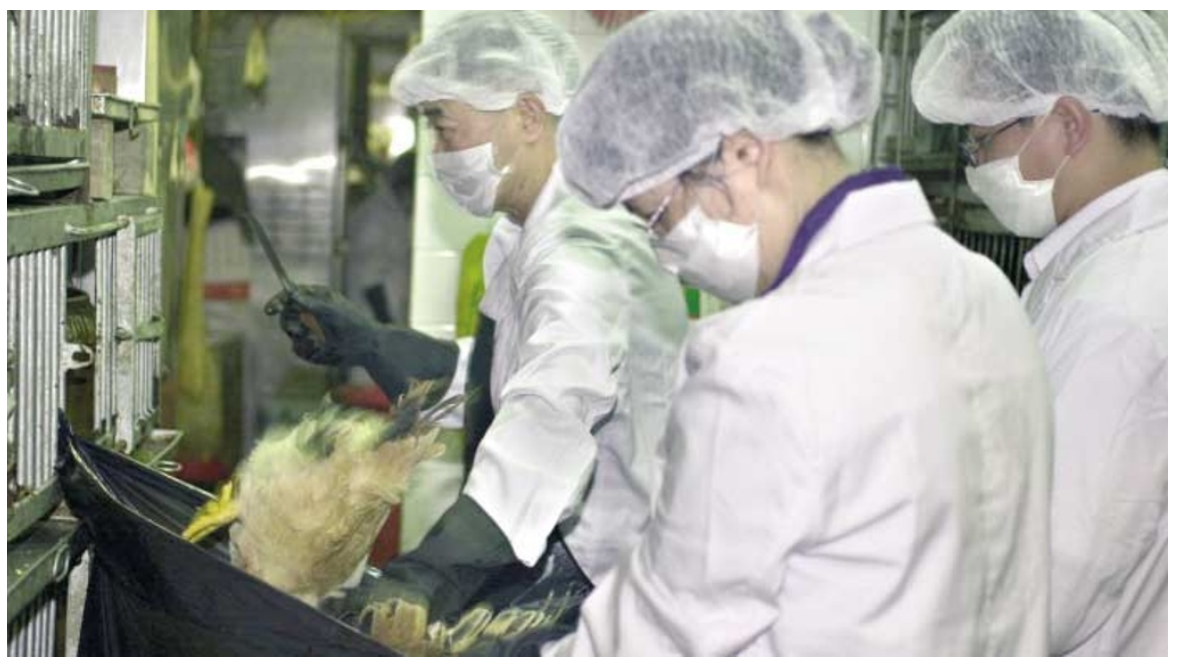

Culling spree: Hong Kong health officials have killed 1.3 million fowl in an attempt to beat the flu.

Ken Shortridge, a microbiologist at Hong Kong University, agrees that the H5 strains detected this spring were not transmissible to humans. But he says that the viruses were still a threat because they can swap genes with related viruses in other fowl, which could result in a virus that can infect humans. "All of the ingredients for generating a virus like the deadly one in 1997 were in the poultry markets this spring," Shortridge says.

In the wake of the outbreak, Hong Kong has stepped up sanitation rules, stipulating that markets be disinfected once a month and that chickens be segregated from other fowl.

The government is now considering using different tests to detect $\mathrm{H} 5$. In the past, it relied on testing for a bird's immune response to the virus. But now DNA-based techniques have been developed by a local biotechnology company, Hong Kong DNA Chips.

Government scientists who control the testing claim that the DNA tests cannot replace immune tests, and have confined their use to confirming results. But the DNAbased tests are quicker, and the government is under pressure to use them more widely.

Most of Hong Kong's chickens come from mainland China, which raises the politically sensitive question - on which no-one Nature interviewed would comment - of whether inadequacies in China's export regulation are allowing the virus into the territory.

\section{Disgruntled homeopathists seek remedy in court}

\section{Alison Abbott}

A leading Italian television presenter is being sued by two homeopathy organizations for failing to include their views in a broadcast of his prime-time science programme Superquark.

Millions of Italians use homeopathic products - which purport to treat diseases using vanishingly small doses - and the homeopathists claim that the broadcast was unfair and could threaten their business. They complain that Piero Angela, who produces his own show, selected only interviewees who were critical of homeopathy for a show that was broadcast last July.

But Angela has received strong backing from the scientific community. He says that he has received many letters of support from individual researchers, including Nobel prizewinners Renato Dulbecco and Rita Levi-Montalcini.

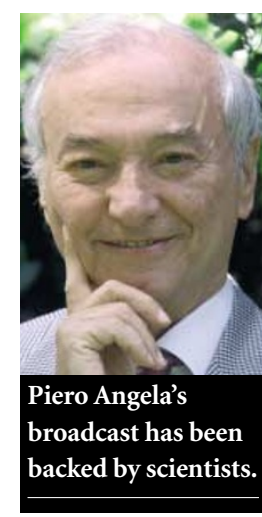

Angela says that Italian public television archives show that that 14 times more programmes had been broadcast advocating homeopathy than criticizing it. His programme sought to redress the balance, he says. He also argues that it is not his job to tell viewers what they want to hear: "Science is not like philosophy, where viewers can listen to both sides and decide for themselves," he says. "Science cannot be decided on by the vote of viewers."

One of the guests on Angela's show was Antonio Cassone, head of the department of bacteriology at the Istituto Superiore di
Sanità, Italy's national health institute, who is a member of the ministry of health's ad hoc committee on homeopathy.

On the show, Cassone says, he merely offered the opinion that safety information should be provided on all homeopathic products, and that efficacy information should be provided on anything that is to be injected. "I would have had no objection to a homeopathist sharing the show," he says, "because it would have been even more convincing to the viewers that arguments of homeopathists against providing information are untenable." But he fully supports the way Angela produced his programme.

The suits, one civil and one criminal, have been brought by the Catania-based Italian Association of Medical Homeopathy and the Rome-based Italian Federation of Associations of Medical Homeopathy. The cases should come to court in the autumn. 